\title{
Effect of Different Shade Levels on Growth and Yield Performances of Cauliflower.
}

\author{
P. G. C Yasoda, L. Pradheeban, K. Nishanthan and S. Sivachandiran
}

Department of Agronomy, Faculty of Agriculture, University of Jaffna,Sri Lanka.

\begin{abstract}
An experiment was conducted during March to July in 2017 (off season) at the Faculty of Agriculture, University of Jaffna, Ariviyal Nagar, Kilinochchi to study the effects of different shade levels on growth and yield performances of cauliflower. Different shade levels such as $25 \%$ (open field), $50 \%$ (single net house) and $75 \%$ (double net house) were used as treatments. The experiment was conducted in completely randomized design (CRD) with four replications. Parametric (growth \& yield) analysis were done by using SAS 9.1 package. The influence of environmental variables such as temperature, relative humidity and light intensity were also studied.The result revealed that growing of cauliflower in different shade levels showed great influence on plant growth and yield attributes. There were significant variations in number of leaves, plant height,curd weight, curd diameter and curd circumference of cauliflower under different light intensities. Light intensity in the shade net house was lower than in the open field. The highest vegetative growth and yield were observed in cauliflower which was grown in $50 \%$ shade levels and the lowest yield was in $25 \%$ shade level (open field). It can be concluded that cauliflower can be cultivated in $50 \%$ shade levels successfully to produce quality curd during off season of the dry zone of Sri Lanka.
\end{abstract}

Keywords-Cauliflower, growth, shade levels, yield.

\section{INTRODUCTION}

Agriculture is closely related to the Sri Lanka because of the country's fertility and the different agro climatic zones which are ideal for crop cultivation. The vegetable sub sector is the most important in agricultural sector next to the rice. As with rice, vegetables are grown throughout the country and large numbers of farmers are engaged in this cultivation (Rupasena, 1999). The cool and healthy climatic conditions in the hill country are ideal for temperate vegetable (exotic) crops such as carrot, leek, cabbage, cauliflower, salad leaves, beet, bean, bell pepper and salad cucumber and climatic conditions in the low and mid country are suitable for tropical vegetable crops. Among the exotic vegetables cultivated in Sri Lanka, cauliflower is cultivated in large extent due to its nutritional value and market demand.

Cauliflower (Brassica Oleracea Var. botrytis L.) belongs to the family of Brassicaceae originated from Europe and Africa (Ajithkumaret al., 2014). Most daily consumed important vegetable of commercial crop in the world. It also has good demand in Sri Lanka. Consuming cauliflower is useful to fight against cancer,boost heart health,rich in vitamins and mineralsboost brain health,detoxification support and digestive benefits. In cauliflower, the edible curd is made up of abortive flowers. The stalk of cauliflower is short, fleshy and closely crowded (Shanmugavelu, 1989). The growers can cultivate a crop in any season under protected environment, as he can provide the temperature, humidity and light, as required by the plant species.

The optimum monthly temperature requirement for cauliflower is 15 to $20^{\circ} \mathrm{C}$ with an average maximum of $25^{\circ}$ $\mathrm{C}$ and average minimum of $8^{\circ}$ C.Plants require light for optimum growth and development, but the three different aspects of light, quantity, quality and duration, also have a significant influence on growth. A plant under natural conditions receives light from the sun; the amount, quality and duration greatly depend on the season of the year, hour of the day, geographical location and weather. Plants use light as a source of energy for photosynthesis. It is primary metabolites in plants (Kopsell, Kopsell, 2008; PerezBalibreaet al., 2008). The carbohydrates produced during photosynthesis are stored and used by the plant as a food source. Light intensity can affect plant canopy, flowering, leaf size, and colour in both herbaceous (Jeonget al. 2009; Vendrameet al. 2004) and woody species (Hampson et al. 1996).

Sri Lanka is a tropical country and shade nets are used to grow the quality temperate vegetable crops which reduce the crop damages due to heavy rain falls and high solar radiation. In addition, it minimizes the pest and disease damages in many parts of the country. Cultivating the crops under shade nets are needed compulsorily for cultivation of hybrids and some exotic crop varieties because they have are susceptible to extreme external environmental conditions. In net houses, 
the plant growth and productivity can be manipulated by modifying light quantity (Wheeler, 2008). Cauliflower is highly sensitive to pest attack and it is ideal for cool climate. Therefore, growing of this crop under shade condition is ideal in dry zone of Sri Lanka especially during off season to reduce the effect of light intensity and pest incidence to this crop.

There are studies available regarding effect of shade levels on growth and yield performances of cauliflower and other exotic vegetables in the world and few studies are available in Sri Lanka, but none of the study was done in Dry zone of Sri Lanka during off season. To overcome this gap, a research study was carried outwith an objective of evaluating the performance of the cauliflower under different shade levels in Kilinochchi district during off season with the sub objectives of the following,

i. To study the effect of different shade levels on morphological characteristics of cauliflower.

ii. To study the effect of different shade levels on yield of cauliflower.

\section{MATERIALS AND METHODS}

A field experiment was carried out at the Faculty of Agriculture, Ariviyal Nagar, Kilinochchiwhich is located at Northern Province of Sri Lankabelongs to the agroecological region of Low Country Dry Zone $\left(\mathrm{DL}_{3}\right)$ to evaluate the effects of different shade levels on the growth and yield performances of cauliflowerduring the period of

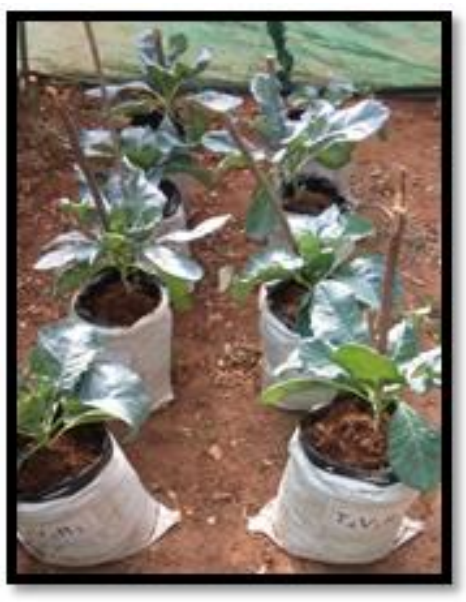

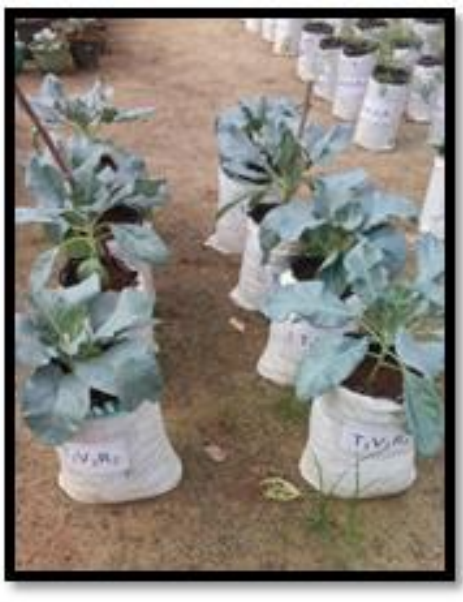

$50 \%$ shade level

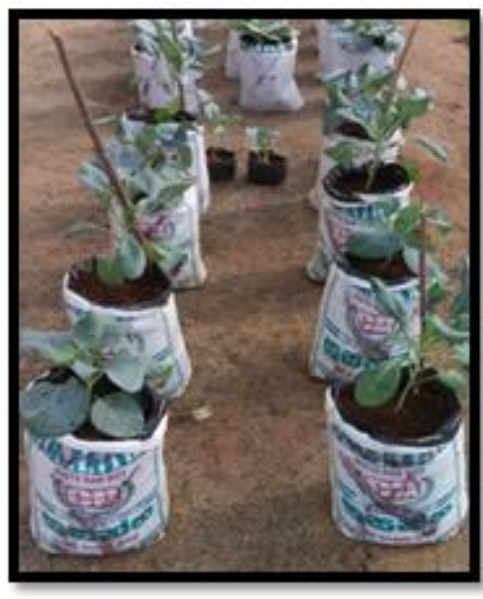

$75 \%$ shade level

March to July 2017. Experiment was conducted in Completely Randomized Design (CRD) with four replications. The cauliflower variety MareetF $_{1}$ was selected due to its excellent performance in warm conditions.

Treatments were

- $\mathrm{T}_{1}-50 \%$ shade level ( Single net house)

- $\mathrm{T}_{2}-75 \%$ shade level (Double net house)

- $\mathrm{T}_{3}-25 \%$ shade level (Open field)

For nursery preparation,Seeds were treated with captan and sowed in a nursery tray with dimensions of $22.5 \mathrm{~cm}$ in width and $52.5 \mathrm{~cm}$ in length consisting of cells dimensions of $6.25 \times$ $6.25 \times 6.25 \mathrm{~cm}$ each. Rooting media was prepared by using top soil, compost and cattle manure at the ratio of 1:1:1 and treated with fungicide captan. Three seeds were planted per cell. Cauliflower seeds germinated 2 days after sowing. Three weeks after germination uniform size cauliflower seedlings were planted in $45 \mathrm{~cm}$ height and $22 \mathrm{~cm}$ width poly bags filled with same rooting media used in the nursery and as 3 seedlings per bag. After the successful establishment of the seedlings, one vigorous healthy seedling was allowed per bag. Cauliflower bags were arranged according to recommended spacing of $60 \mathrm{~cm} \times 45 \mathrm{~cm}$. After planting watering was done by water can and the surface soil was kept in wet condition, but excess watering was avoided. All other management practices were given as recommendation made by Department of Agriculture.The bag arrangements were shown in the plate 1 .

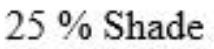

Plate 1. Cauliflower under different shade levels

At the time of curd formation, blanching was done in cauliflower. Leaves were tied up with twine to protect the curd from sun burning and browning (Plate 2). 


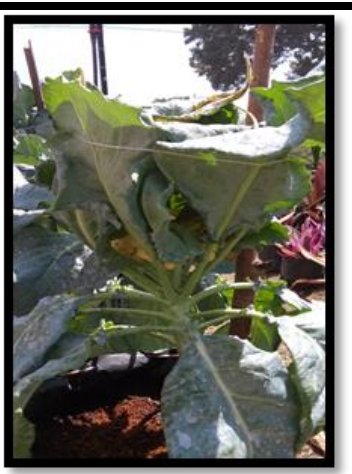

Plate 2: Blanching of cauliflower

Harvesting was done 65 to 80 days after transplanting, when curd reach the proper size, bright white colour and compactness.

Measurements:

\section{Weather Parameters}

Light intensity, average temperature and average humidityat each shade levels were measured

\section{Growth Parameters}

Plant height and number of leaves per plant were taken at biweekly interval commencing from 3 weeks after transplanting.

\section{Yield Parameters}

The yield components of cauliflower curd such as weight, diameter and circumference were measured during harvesting time.

\section{Data Analysis}

The ANOVA was performed by using GLM procedure of the SAS 9.1 computer software package.

\section{RESULTS AND DISCUSSION}

The results obtained from this research study were discussed in this chapter.

\section{Light Intensity}

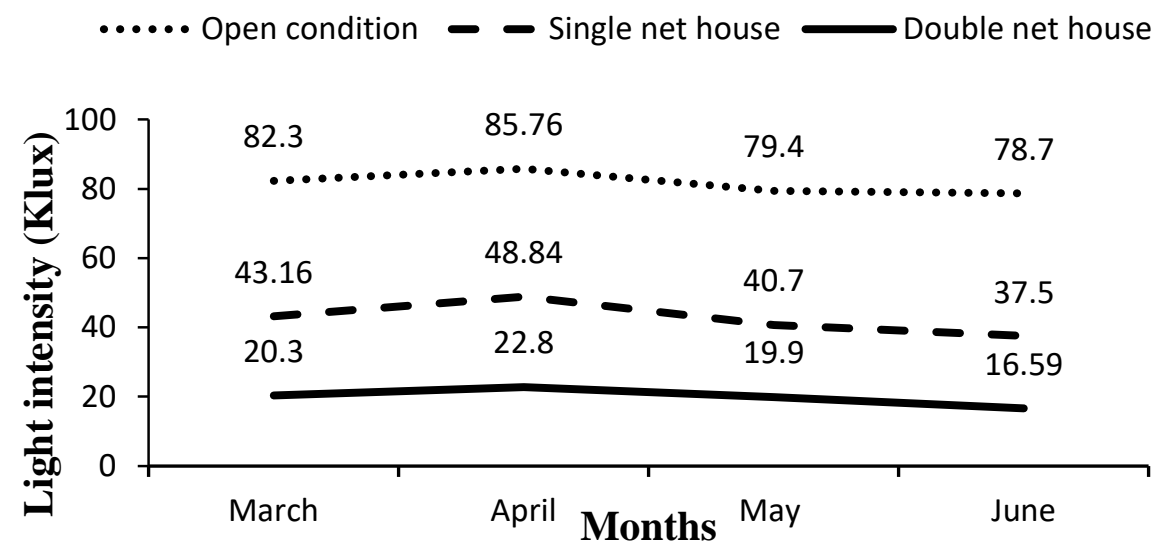

Fig.1: Mean light intensity (klux) from March to June during Experimental period

Mean light intensity was higher in open field condition and maximum light intensity was observed during April than other months (Figure 1). Nangareet al. (2015) reported that shade nets reduced both light intensity and heat effectively during the daytime while changing the spectrum. He also stated that the significant difference was observed in solar radiation in open condition and inside the shade nets.

\section{Average temperature}

Table.1: Average temperature from March to June during the Experimental period

\begin{tabular}{l|llll}
\hline \multirow{2}{*}{ Treatment } & \multicolumn{4}{|c}{ Months } \\
\cline { 2 - 5 } & March & April & May & June \\
& & & & \\
\hline Open field condition & $32.8^{\circ} \mathrm{C}$ & $37.8^{\circ} \mathrm{C}$ & $35.4^{\circ} \mathrm{C}$ & $34.8^{\circ} \mathrm{C}$ \\
Single net house & $31.4^{\circ} \mathrm{C}$ & $38.8^{\circ} \mathrm{C}$ & $35.7^{\circ} \mathrm{C}$ & $35.8^{\circ} \mathrm{C}$ \\
Double net house & $31.3^{\circ} \mathrm{C}$ & $38.1^{\circ} \mathrm{C}$ & $35.2^{\circ} \mathrm{C}$ & $35.1^{\circ} \mathrm{C}$ \\
\hline
\end{tabular}

\section{Average relative humidity}


Table.2: Average relative humidity during the Experimental period

\begin{tabular}{l|llll}
\hline \multicolumn{1}{c|}{ Treatment } & \multicolumn{3}{|c}{ Months } \\
\cline { 2 - 5 } & March & April & May & June \\
\hline Open condition & $58.1 \%$ & $48.6 \%$ & $50.4 \%$ & $50.0 \%$ \\
Single net house & $59.7 \%$ & $48.1 \%$ & $49.4 \%$ & $49.2 \%$ \\
Double net house & $59.3 \%$ & $47.0 \%$ & $49.8 \%$ & $49.1 \%$ \\
\hline
\end{tabular}

There was no much variation in average temperature and relative humidity during the experimental period of March to June among different treatments (Tables 1 and 2).

Nangareet al. (2015) stated that there was no significant difference found in average monthly temperature and humidity inside shade net house and open field condition (control).Sajjapongse and Raon (1983) observed the poor head formation, leaf twisting, early bolting and reduced yields when temperate leafy vegetables were grown under hot, high sunlight conditions. Smith et al. (1984) also observed that under shading nets, the air temperature was lower than that of the ambient air temperature, depending on the shading intensity. Shade netting not only decreases light quantity but also alters light quality to a varying extent and might also change other environmental conditions.
Growth and yield performance of cauliflower also depends on the season of cultivation. Experimental period was unsuitable season (off season) to cultivate cauliflower. Off season cultivation showed poor growth and yield than proper time of cultivation. Swagatikaet al. (2006) observed that cauliflower sown in the month of September and grown under shade net recorded the highest values for plant height, number of leaves, girth and curd yield.

\section{Number of Leaves}

Number of leaves is one of the important growth parameter which influenced by genetic and environmental factors. Leaf is the primary source of photosynthesis. Formation of leaves in cauliflower was significantly influenced by different shade levels.

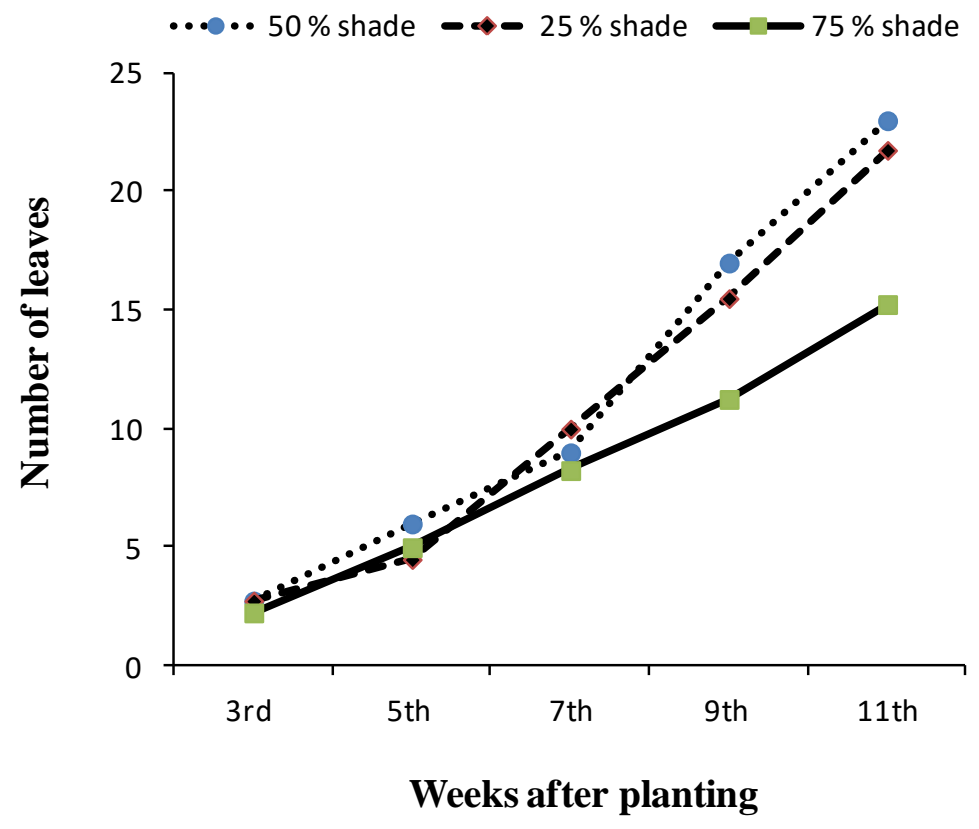

Fig.2: Number of leaves of cauliflower at biweekly interval

The leaves growth in cauliflower was significantly differed with different shade levels. The highest number of leaf formation was recorded in $50 \%$ shade level and the lowest number of leaves was recorded in $75 \%$ shade level (Figure 2 ). This might be due to the favourable effect of $50 \%$ shade net which had increased photosynthetic process in cauliflower due to favourable micro climate.

\section{Plant Height}




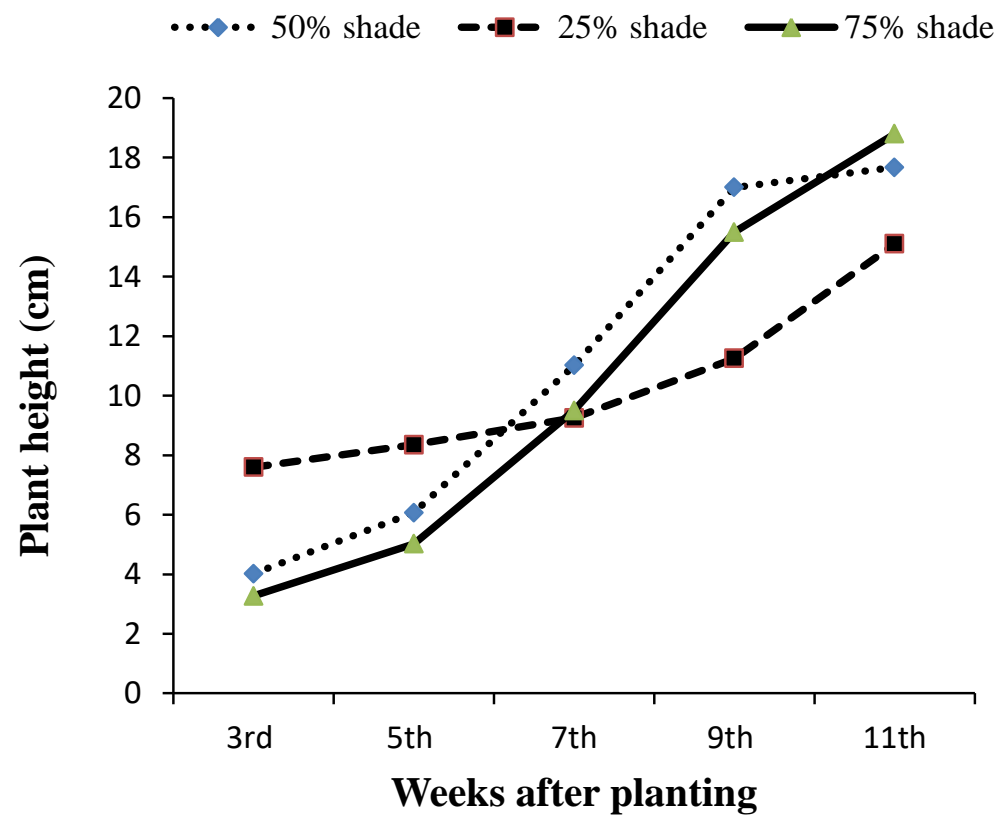

Fig.3: Average plant height of cauliflower at biweekly interval

The plant height of cauliflower was significantly influenced under different shade levels throughout the crop growing period. Plant height of cauliflower gradually increased and it was significantly differed among different treatments (Figure 3). The highest height was observed in $75 \%$ shade level that would be due to elongation of internodes to capture more light. Different shade levels could alter the other environmental conditions and develop suitable micro climate inside the shade netswhich may be the reason for differences in plant height and number of leaves under different shade levels. Same results also reported by Swagatikaet al. (2006), Eladet al. (2007), Vethamoni and Natarajan (2008), Haqueet al. (2009) and Rajasekaret al. (2013).

\section{Mean Curd Weight}

The number of days required for curd initiation was influenced due to different shade levels. The curd initiation was found to be earlier in 50 per cent shade level. Late curd initiation was observed in $25 \%$ shade level and curd was not initiated under 75 percent shade level. Mean curd weight of cauliflower was significantly differed. Among treatments, $50 \%$ shade level $\left(\mathrm{T}_{1}\right)$ gave the highest weight than other treatments. When increasing the shade level, mean head weight was decreased. The highest curd weight of $285 \mathrm{~g}$ was obtained in $50 \%$ shade level $\left(\mathrm{T}_{1}\right)$ which was statistically significant from other two treatments. The lowest curd weight of $160.03 \mathrm{~g}$ was obtained from $\mathrm{T}_{3}$ (open field). There was no curd formation in $75 \%$ shade level that could be due to the inadequate light intensity and low photosynthetic activity. Results showed that cauliflower performed well under $50 \%$ shade level. This might be due to the favourable environmental conditions such as light intensity, temperature and relative humidity in $50 \%$ shade levels which had increased photosynthetic process and assimilate accumulation in cauliflower. Similar results were also reported by Swagatikaet al., (2006) and Vethamoni and Natarajan (2008) in cauliflower. 


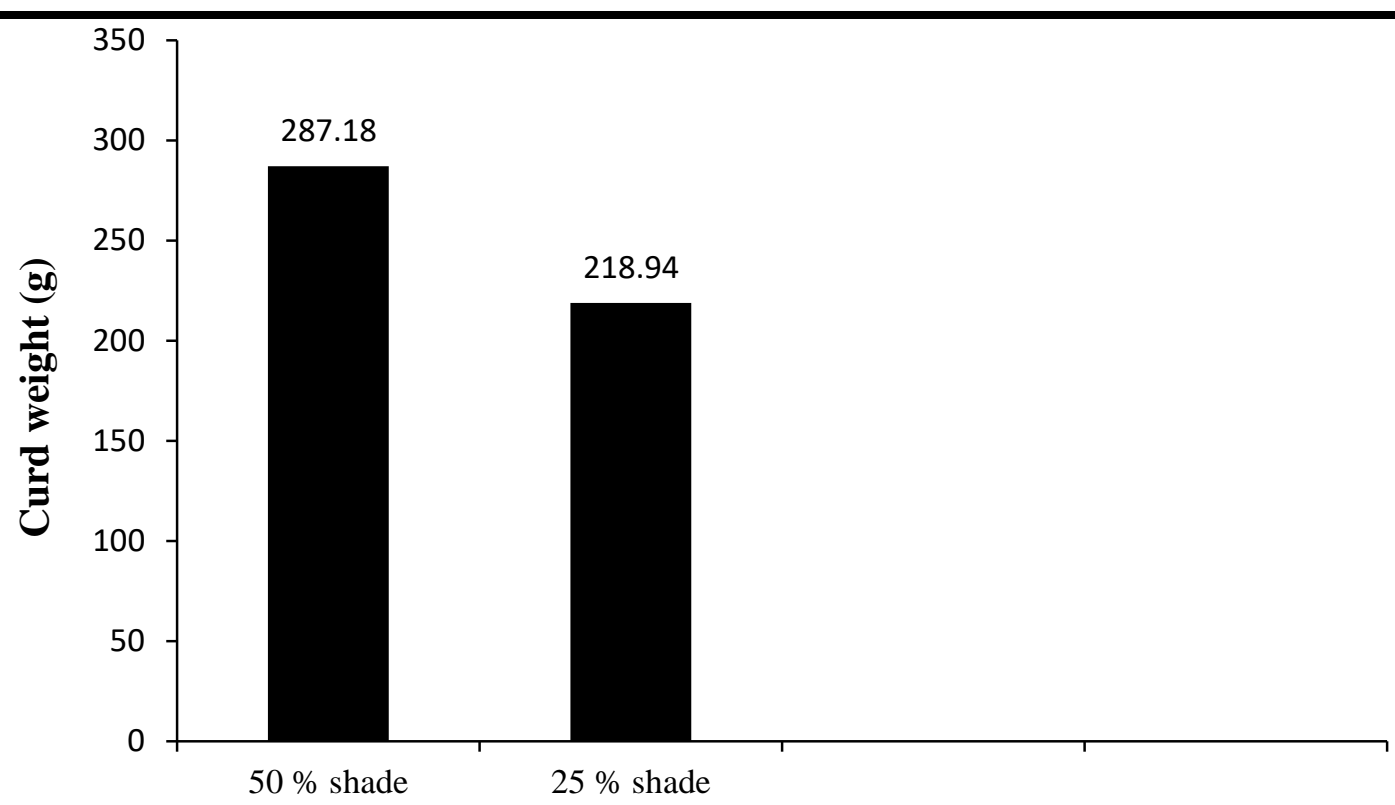

Shade levels

Fig.4: Mean curd weight of cauliflower

\section{Mean Curd Diameter}

There was a significant differences was observed in $50 \%$ shade and open field treatments (Figure 5). Maximum curd diameter of $22.53 \mathrm{~cm}$ was obtained from $50 \%$ shade level $\left(\mathrm{T}_{1}\right)$ and minimum curd diameter of $18.53 \mathrm{~cm}$ was obtained from $25 \%$ open field condition $\left(\mathrm{T}_{3}\right)$. This may due to favourable condition in $50 \%$ shade levelthat caused to form compact quality curd. Under high temperature and light effect in open field conditioncurds were perform poorly than $50 \%$ shade level.

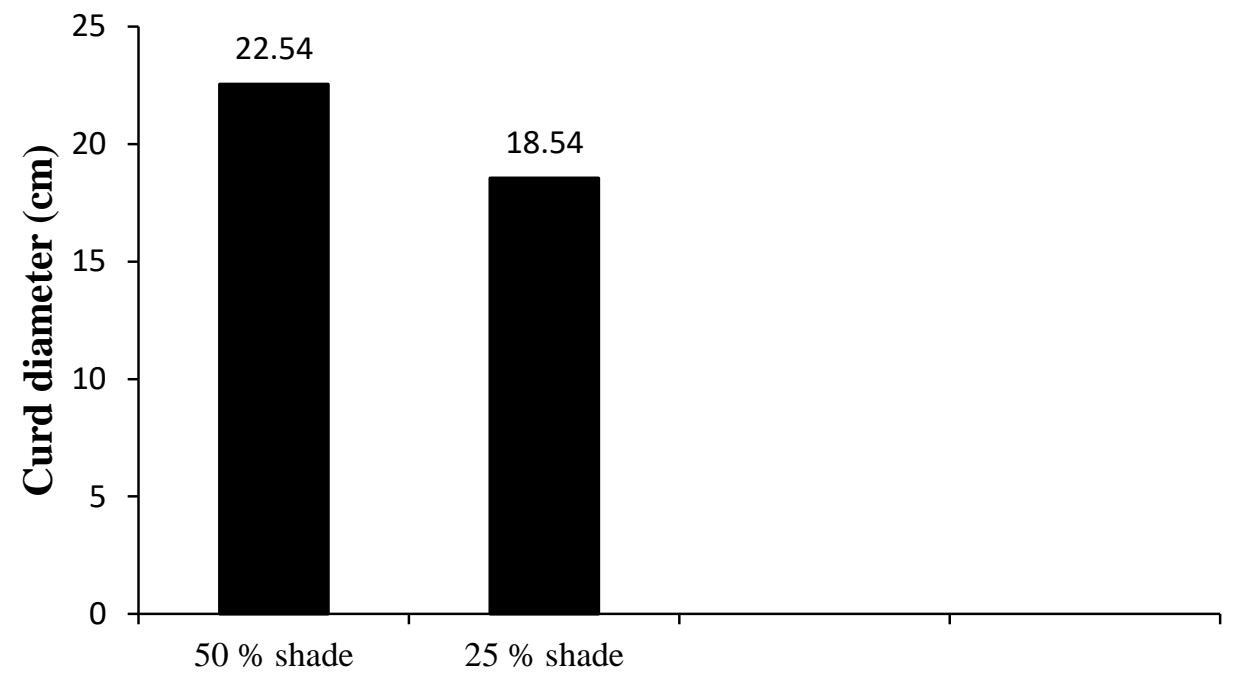

Shade levels

Fig.5: Mean curd diameter of cauliflower

\section{Mean Curd Circumference} mean curd circumference of cauliflower (Figure 6). The 
maximum curd circumference of $38.88 \mathrm{~cm}$ was recorded in $25 \%$ shade levelwith more volume in curds than other treatments. Under lower shade level temperature and light intensity were high it promote more growth of curd. Lower shade level gave more volume curds but curds were loosely arranged and not well compacted.

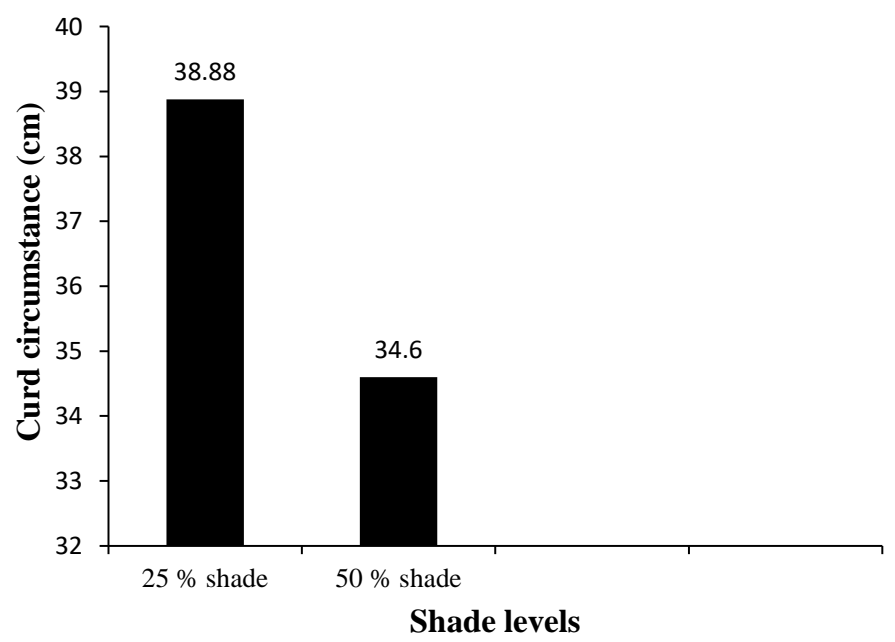

Fig.6: Mean curd circumference of cauliflower

\section{CONCLUSIONS}

Cauliflower cultivation in Ariviyal Nagar, Kilinochchi was significantly influenced by the season and weather conditions. Growing of cauliflower under different shade levelsshowed great influenced on its growth and yield performance. Numbers of leaves were high in $50 \%$ shade level (single net) than other shade levels. Average plant height of cauliflower increased with increasing shade levels. The highest plant height was in $75 \%$ shade level than other shade levels. The highest mean curd weight and curd diameter were in $50 \%$ shade level than $25 \%$ shade level (open field) condition. Good quality, compact curds were produced at $50 \%$ shade levels than other shade levels. The highest mean curd circumference was in $25 \%$ shade level (open field) than $50 \%$ shade level.

\section{SUGGESTION}

Other levels of shade and naturally available shade scan also be used as shade level and experiment can be repeated for different varieties in both Maha and Yala seasons to get consistency.

\section{REFERENCES}

[1] Ajithkumar, B., Karthika, V. P. and Rao, V. U. M. (2014). Crop weather relationships in Cauliflower (Brassica oleraceavar. Botrytis L.) in the Central zone of Kerala. AICRP on Agrometeorology, Department of Agricultural Meteorology College of Horticulture, Kerala Agricultural University.
[2] Elad, Y., Messika, Y., Brand, M., David, D.R. and Sztejnberg, A. (2007). Effect of coloured nets on pepper powdery mildew. Phytoparasitica. 35(3):285299.

[3] Hampson, C.R., Azarenko, A.N., and Potter, J.R. (1996). Photosynthetic rate, flowering, and yield component alteration in hazelnut in response to different light environments.J.Amer.Soc.Hort.Sci121:1103-1111.

[4] Haque, M.M., M Hassanuzzaman, M. and Rahman,.L. (2009). Effect of light intensity on morpho-physiology and yield of bottle gourd (Longenaria vulgaris). Acad. J. Plant Sci. 2(3): 158-161.

[5] Jeong, K.Y., Pasian, C.C., McMahon, M., and Tay, D.(2009). Growth of six Begoniaspecies under shading. Open Hort. J. 2:22-28.

[6] Kopsell, D. A. and Kopsell, D. E. (2008). Genetic and environmental factors affecting plant lutein/zeaxanthin. Agro Food Industry Hi-Tech, 19: 44-46.

[7] Nangare, D. D., Singh, J., Meena, V. S., Bhushan, B. and Bhatnagar, P. R. (2015).Effect of green shade nets on yield and quality of tomato (LycopersiconesculentumMill) in semi-arid region of Punjab.Asian J. of Adv.in Basic and Applied Sci., Vol.1: (1):1-8.

[8] Perez-Balibrea, S., Moreno, D. A. and Viguera, C. G. (2008). Influence of light on health promoting 
phytochemicals of broccoli sprouts. Journal of the

Science of Food and Agriculture, 88: 904-910.

[9] Rajasekar, M., Arumugam,.T. and Ramehkumar, S. (2013). Influence of weather growing environment on vegetable growth and yield. J. Hort (10): 160-167.

[10] Rupasena, L.P., (1999): Production and Marketing of Vegetables, Research study No. 102, HARTI, Colombo, $1-26$.

[11] Sajjapongse, A. and Roan, Y.C. (1983).Effect of shading and leaf-tying on summer Chinese cabbage.HortScience 18:464-465.

[12] Shanmugavelu, K.G. (1989). Production technology of vegetable crops. Oxford \& IBHPublishing ,New Delhi-110001, 661.

[13] Smith, I. E., Savage, M. J. and Mills, P. (1984). Shading effects on greenhouse tomatoes and cucumbers. Acta Hort. 148: 491-500.

[14] Swagatika Srichandan, Panda, S.C., Sahu, G.S., Mahapatra, P. and Mishra, R. (2006).Effect of Shade net on growth and yield of cauliflower. Orissa J. Horticulture. 34(1): 28-31.

[15] Vendrame, W., Moore, K.K., and Broschat, T.K. (2004). Interaction of light intensity and controlledrelease fertilization rate on growth and flowering of two New Guinea impatiens cultivars. Hort Technology 14:491-495.

[16] Vethamoni, P.I. and Natarajan, S. (2008).Cultivation of sweet pepper cultivars (Capsicum annuum var. grossum L.) under shade net in tropical plains of Tamil Nadu. Asian J. Hort. 3(2): 372-376.

[17] Wheeler R. M. (2008). A historical background of plant lighting: an introduction to the workshop. HortScience, 43 (7): 1942-1943. 